2018.01.

<DIGITÁLIS BÖLCSÉSZET>

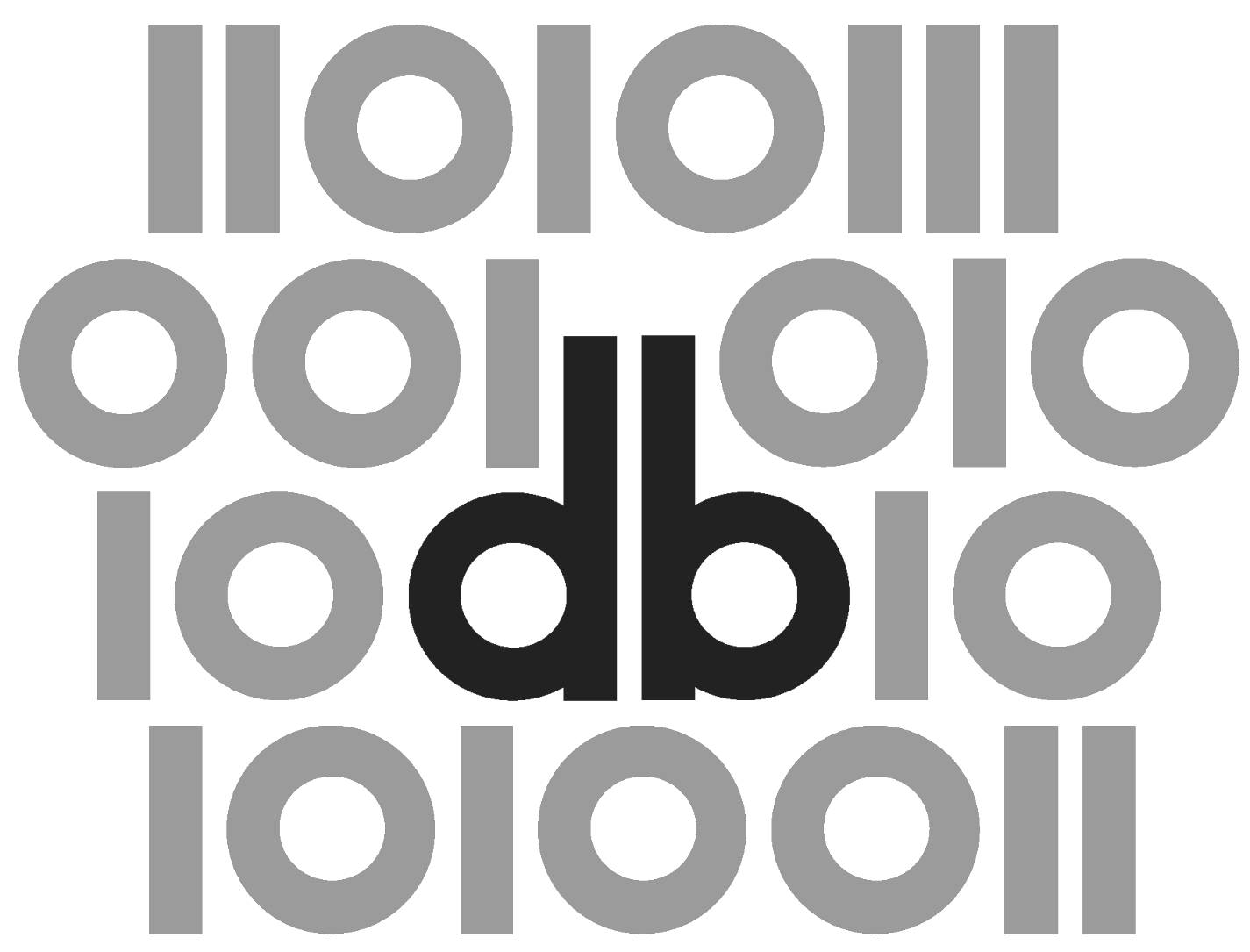

2018.01.

</DIGITÁLIS BÖLCSÉSZET> 
Digitális Bölcsészet 2018., első szám 


\section{〈DIGITÁLIS BÖLCSÉSZET>}

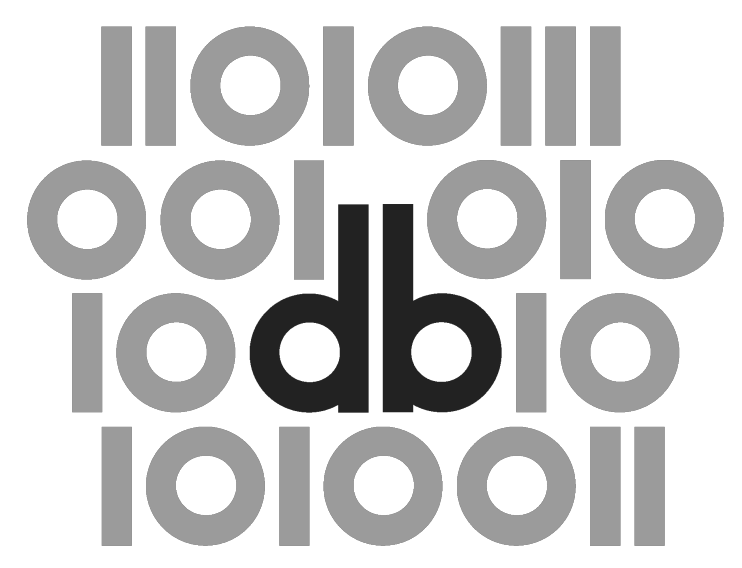

2018.01. 
Felelős szerkesztő :

Maróthy Szilvia

Szerkesztőbizottság:

Bartók István, Fazekas István, Golden Dániel, Horváth Iván (a bizottság elnöke), †Orlovszky Géza, Palkó Gábor, Pap Balázs, Sass Bálint, Seláf Levente

\section{Szerkesztőség:}

Almási Zsolt, Fodor János, Kokas Károly, †Labádi Gergely, Parádi Andrea

Rovatvezetők:

Tanulmányok: Kiss Margit

Mühely: Péter Róbert

Kritika: Bartók Zsófia Ágnes

ISSN 2630-9696

DOI 10.31400/dh-hun.2018.1

Kiadja az ELTE BTK Régi Magyar Irodalom Tanszéke, 1088 Budapest, Múzeum krt. 4/A.

Felelős kiadó az ELTE BTK Régi Magyar Irodalom Tanszék vezetője.

Megjelenik az Open Journal Systems (OJS) v. 3. platformon, melynek működtetését az ELTE Egyetemi Könyvtár- és Leváltár biztosítja.

Honlap: http://ojs.elte.hu/index.php/digitalisbolcseszet Email cím:dbfolyoirat@gmail.com

Tördelés: Hegedüs Béla

Grafika: Hegyi Gábor 


\section{Tartalom}

Beköszöntő

Prószéky Gábor előszava _. . . . . . . . . . . . . . . . . 9

Andrew Prescott előszava . . . . . . . . . . . . . . . . . . . . 11

Szerkesztőségi köszöntő . . . . . . . . . . . . . . . . . . . . 13

$\begin{array}{ll}\text { Tanulmányok } & 15\end{array}$

Labádi Gergely

Az olvasó gép: Berzsenyi Dániel versei távolról _ . . . . . . . . . . . 17

Drótos László-Kokas Károly

Webarchiválás és a történeti kutatások . . . . . . . . . . . . 35

Markó Anita

Hálózatok a 16-17. századi album amicorumokban: Az 1500 és 1700

közötti hungarika jellegű emlékkönyvbejegyzések hálózatelemzése az

Inscriptiones Alborum Amicorum adatbázis alapján . . . . . . . . . . . . 55

Matthew L. Jockers

Metaadat ...................... 83

$\begin{array}{ll}\text { Mühely } & 109\end{array}$

Sennyey Pongrácz

Viták és víziók a digitális bölcsészetről _ . . . . . . . . . . . . . 111

Horváth Iván

Digitális bölcsészet a virtuális nemzeti könyvtárban . . . . . . . . . . 121

Lejtovicz Katalin-Matthias Schlögl-Bernád Ágoston Zénó-Maximilian Kaiser-

Peter Alexander Rumpolt

Digitalizáció és hálózatkutatás:

Az Österreichisches Biographisches Lexikon 1815-1950 és az APIS-projekt 139

Cséve Anna-Fellegi Zsófia-Kómár Éva

Móricz Zsigmond levelezésének (1892-1913) digitális kritikai kiadása

Esettanulmány . . . . . . . . . . . . . . . . . . . . . . . . . . . . 159

Biszak Sándor-Kokas Károly

Budapest Időgép ～. . . . . . . . . . . . . . . . . . 175

Ruttkay Zsófia

Digitális Múzeum - a MOME TechLab projektjeinek tükrében . . . . . 185

Dragon Zoltán-Sebestény Csilla

\#BREW : influencer-kísérlet az Instagram újhullámos kávéközösségében 203 
Matthew James Driscoll and Elena Pierazzo, eds., Digital Scholarly Editing: Theories and Practices (2016) - Maróthy Szilvia . . . . . . . . . . . . . . 219 Laura Estill, Diane K. Jakacki and Michael Ullyot, eds., Early Modern Studies after the Digital Turn (2016) - Maczelka Csaba . . . . . . . . . . . . . 223 Matthew K. Gold, ed., Debates in the Digital Humanities (2012); Matthew K. Gold and Lauren F. Klein, eds., Debates in the Digital Humanities 2016 (2016) - Zámbóné Kocic Larisa . . . . . . . . . . . . . . . . . . . . . 233 George Bruseker, László Kovács and Franco Niccolucci, eds., „Digital Humanities." ERCIM News 111 (2017) - Molnár Sándor Gyula . . . . . . . . 239

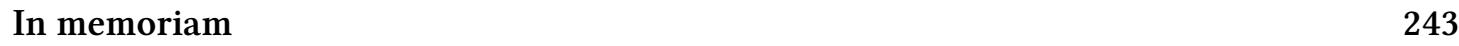

Szajbély Mihály: Búcsú Labádi Gergelytől . . . . . . . . . . . . . . . . . 245 


\title{
Sennyey Pongrácz
}

St. Edward's University Library, Austin, Texas

pongracz@stedwards.edu

\section{Viták és víziók a digitális bölcsészetről}

\begin{abstract}
A cikk áttekinti az Amerikai Egyesült Államokban lezajlott digitális bölcsészet körüli legújabb vitákat, és összefoglalja azok főbb érveit. Az írás számos kérdést kiemel e vitából, például hogy milyen kritériumokat kell egy projektnek teljesítenie ahhoz, hogy azt digitális bölcsészetnek lehessen minősíteni, valamint hogy a digitális bölcsészet tudományágnak vagy inkább módszertannak tekinthető. Új infrastruktúrát kell kifejleszteni ahhoz, hogy a kutatók megkaphassák a szükséges támogatottságot digitális bölcsészeti projektek megvalósíthatóságához. Az írás végül azt taglalja, hogy a jövőre vonatkoztatva az e tárgykörbe tartozó diskurzusoknak milyen következményei lehetnek a bölcsészettudományokra.
\end{abstract}

Kulcsszavak:

digitális bölcsészet, digitális infrastruktúra, digitális módszerek

Amióta a digitális bölcsészet fogalma megjelent, viták vannak körülötte. Ezek a viták hol a kifejezés szabatos értelmezéséről szólnak, hol arról az alkalmazott eszközkészletről, amelyeket e terület kutatói alkalmaznak, hol pedig az ebben a kontextusban született új tudományos eredményekről folyik a diskurzus. Ezeknek a kérdéseknek a tárgyalása Magyarországon sem ismeretlen, konferenciákon és szakcikkekben is találkozni velük. Az látszik belőlük, hogy e kérdések egyre kifinomultabban és árnyaltabban újra és újra felmerülnek. Az elmúlt években ezek a viták felerősödtek az Egyesült Államokban, és különböző megközelítések jelentek meg úgy a tudományos folyóiratokban, mint a témához kapcsolódó hetilapokban is.

A vitákat érdemes követnünk Magyarországon is, mert nagyon tanulságosak lehetnek a hazai szakemberek számára akkor is, ha még az amerikai kollégák sem találták meg a bölcsek kövét. A diskurzusokat - az áttekinthetőség kedvéért - öt alapvető témára lehet bontani, ha ezzel némiképp le is egyszerűsítjük a valójában igen komplex megszólalásokat.

\section{Eszközhasználat?}

Az első téma, amelyről vita bontakozott ki, az alkalmazott eszközökről szól. ${ }^{1}$ Az a kérdés, hogy milyen eszközök használatával válik egy tudományos projekt digitális

1 Timothy Brennan, „The Digital-Humanities Bust,” Chronicle of Higher Education, 2017. okt. 15., http: ://www.chronicle.com/article/The-Digital-Humanities-Bust/241424. 
bölcsészetivé. Ha számítógépe(ke)t alkalmaz a kutató a munkában, az már elegendő hozzá? Vagy szükséges valamiféle speciális algoritmust is futtatnia? S egy ilyen célszoftver alkalmazása elegendő kritérium? Felmerül az a kérdés is, hogyha például a kutató létrehoz egy digitalizált gyüjteményt (amelynek az eredetije analóg formátumban már létezett), vagy ha egy korpuszt például XML-formátumba rögzít, akkor az ilyen jellegű projektek digitális bölcsészetnek számítanak? Más szóval, kell-e különbséget tenni a digitális eszközök bölcsészeti használata és magának a digitális bölcsészetnek a fogalma között? Lehet-e pontos határt szabni, kritériumokat kijelölni, hogy jól pozicionált distanciákat tudjunk tenni e két metódus között? Az mindenesetre látszik, hogy eddig nem sikerült a pontos határvonalat meghúzni. Persze az is kérdés, hogy fontos-e pontosan kijelölnünk.

\section{Módszertan?}

A második vitatéma az adat (vagy forrás) feldolgozási módszerei körül forog. ${ }^{2}$ Miféle új módszereket tud a digitális bölcsész alkalmazni, és azzal milyen új eredményeket tud felmutatni? Mivel a digitális bölcsészet számos példát hoz az új kvantitatív módszerek alkalmazásával kapcsolatban (amivel mind nagyobb forrásanyagot tud feldolgozni), ez a vita alapvetően skálákról, skálázhatóságról szól. Az új módszerek (és eszközök) előnye gyakran abban ragadható meg, hogy eddig leküzdhetetlen méretűnek számító szöveg-és adathalmazokat kezelhetővé tud tenni. Gépek és algoritmusok nélkül ezeket lehetetlen lenne/lett volna belátható időn belül feldolgozni. Az is realitássá vált, hogy a digitális bölcsészet - az eddigi esetleges benyomások és vélelmek helyett - korábban elérhetetlen pontossággal és matematikai precizitással rajzolja fel az eredményeket. Ebben az összefüggésben az további vita tárgya lehet, hogy a tudós ilyenkor csak azt tudja az algoritmusaival feldolgoztatni, amit ő maga illesztett be az algoritmus programozásakor - hiszen ma még (!) a kutatónak és nem a számítógépnek a kreativitása és intelligenciája, illetve képessége áll az eredmény mögött. Emiatt kerülnek elő új összefüggések, rajzolódnak ki új mintázatok, válnak láthatóvá új kapcsolódások. Napjainkban még nem tartunk ott, hogy a mesterséges intelligencia segítségével elemezni lehessen ennyire összetett problémákat. Ezek az absztrakt lépések továbbra is a kutató képességeitől (és lehetőségeitől) függenek. Az is igaz ugyanakkor, hogy attól még, hogy a kutató megalkot új fogalmakat, feltesz új kérdéseket, abból még nem feltétlenül következik, hogy be is tudja illeszteni azokat az algoritmusaiba. Valójában két olyan határról van itt szó, amelyeket egyszerre kellene átlépni: egyrészt a nagy mennyiségủ adatok új összefüggéseinek a feltárását, másrészt az informatikai megvalósítás mikéntjét.

\section{Gondolkodásmód?}

Az előbbi viták - gyakran hallgatólagosan - arról is szólnak, hogy a digitális bölcsészet egy újféle gondolkodást hoz előtérbe vagy akár meg is teremt, illetve máshonnan nézve

2 Saulo Cunha de Serpa Brandão and Wander Nunes Frota, „On the Path to a Methodology for the Critique of Digital Literature," Digital Scholarship in the Humanities 32, 2. sz. (2017): 225-233, https : ://doi.org/10.1093/llc/fqw016. 
megköveteli azt. Olyat, amely a természettudományok pontosságát és precizitását vezeti be a humán tudományágakba. Ez az úgynevezett „algoritmikus gondolkodás” (computational thinking). ${ }^{3}$ Ez több szálon visszavezet a „strukturalista iskolák” céljaihoz, amelyek még a 20. század elején, az informatika kibontakozása előtt jelentek meg. Sőt, már korábban is léteztek ilyen tendenciák, láthatóak voltak ilyenféle szemléleti megközelítések, gondoljunk például a híres francia Annales folyóiratra, de akár már a pozitivizmus aranykorában is vannak erre a gondolkodásmódra példák, ilyenek Szinnyei József (1857-1943) hatalmas adatmennyiségeket megmozgató módszerei (nem véletlen emlegették „gőzhangya”-ként kortársai). A megközelítésben voltak hasonlóságok, de persze akkor még kézzel dolgozták fel a forrásanyagot, gyakran hosszú éveket szánva a munkára. Az ilyen tudós - kortársai többségétől egészen eltérő módon - alapvetően máshogyan közelítette meg az anyagát, hiszen számokkal, statisztikai képletekben, eloszlásokban, táblázatokban gondolkodott. Az eredményeket gyakran nem folyamatos narratívákban fogalmazta meg, hanem adatok, grafikonok, táblázatok sorát tárta az olvasó elé, melyek összességükben adtak egészen új megközelítést az adott tudományon belül (tipikus korai és nagyszerű példa erre Fernand Braudel klasszikusa A Földközi-tenger és a mediterrán világ II. Fülöp korában három kötete). ${ }^{4}$

\section{Külön tudomány?}

Olykor a vitában egy harmadik dilemma is felmerül: vajon a digitális bölcsészet maga egy külön tudományág ${ }^{5}$ Ha már a bölcsész tudósok számítógépeket használnak, algoritmusokkal dolgozzák fel az anyagukat, és ebből fakadóan de facto máshogyan is gondolkodnak, akkor az már valószínüleg egy külön tudományágat is jelent - vagy mégsem? Itt persze megkerülhetetlen az a tény, hogy attól még, hogy a digitális bölcsészek máshogy előkészített és új módon megjelenített alapanyagokat dolgoznak fel, és más aspektusból közelítenek hozzájuk - legyenek azok bár történelmiek, irodalmiak vagy éppen müvészetiek stb. -, még akkor is a bölcsészettudományokon belül maradnak és dolgoznak. Érdemes itt a tudománytörténet néhány analógiájára gondolni. Mi történik, ha egy tudományág bevett módszertanában egy egészen új terület bukkan fel? Például a biokémia, kísérleti fizika stb. sorra fontos szakterületekké váltak, de azért az alaptudomány (biológia, kémia, fizika) részei is maradtak, csak egyfajta szakosodást jelentettek. Valójában nem ritka, hogy egy tudományágban éppen az új metodológiák miatt - újabb tudományterület alakul ki, de az ellenkezőjére

3 Adam Kirsch, „Technology is Taking over English Departments,” New Republic, 2014. máj. 2., ht tps://newrepublic.com/article/117428/limits-digital-humanities-adam-kirsch. David M. Berry and Anders Fagerjord, Digital Humanities. Knowledge and Critique in a Digital Age (Malden, MA: Polity, 2017), 40-60.

4 Kokas Károly, „Digitális bölcsészet 2016. A bölcsészek és az informatikai megközelítés: régen és most," MONOKgraphia: tanulmányok Monok István 60. születésnapjára, szerk. Nyerges Judit, Verók Attila, Zvara Edina (Budapest: Kossuth Kiadó, 2016), 405-412, http://publicatio.bibl.u-szeged.hu/10296/. E tanulmány a 2015-ben megrendezett „Digitális bölcsészet Szegeden” címü minikonferencia előadásaira és tanulságaira is támaszkodik. Hozzáférés : 2017.09.15, http: //digib olcsesz.ek.szte.hu/.

5 Alan Liu, „Is Digital Humanities a Field? An Answer from the Point of View of Language, Journal of Siberian Federal University. Humanities and Social Sciences 7 (2016): 1546-1552, https: //doi .o $\mathrm{rg} / 10.17516 / 1997-1370-2016-9-7-1546-1552$. 
is van példa: egy új metodológia megváltoztathat egy tudományágat akár úgy is, hogy nem válik külön tőle, mint például a lézertechnika és a sebészet összekapcsolódása. Összegezve azt állíthatjuk, hogy ma még a digitális bölcsészet pontos helye a tudományterületeken belül, illetve hatása az egyes bölcsészeti tudományágakra nem pontosan tisztázott, és ez a helyzet még valószínüleg egy ideig így is marad. Végül érdemes megjegyezni azt is, hogy vannak olyanok, akik már eleve úgy fogalmaznak: a digitális bölcsészet pontos mibenléte vitatott terület marad a jövőben is. ${ }^{6}$

\section{Divat?}

A legutóbbi vitákban olyan megközelítések is felmerültek, hogy a digitális bölcsészet inkább csak egy divattermék, amelyet az egyetemi vezetők, tudományszervezők és kutatóintézetek használnak kedvezményezett pozíciók elérésére, a tradicionálisan dolgozó kollégáik rovására. ${ }^{7}$ Ezáltal, főleg az Egyesült Államokban, többen úgy érvelhetnek, hogy ők a „korszerűbb” digitális bölcsészetet müvelik, és a fentiekben felvázolt homályos határokat is figyelembe véve, talán nem is tartoznak a szorosabban vett digitális bölcsészet égisze alá. Miután a sikeres (vagy szerencsés) bölcsész így hozzáfér olyan kutatási ösztöndíjakhoz és támogatásokhoz, amelyeket esetleg a hagyományos módszerekkel dolgozó kutatótársai nemigen kapnak meg, ez önmagában vitát eszkalál a „régiek és újak” közt a források elérhetősége tekintetében is. ${ }^{8}$ Nem kevés iróniával közelítik meg ezt a kérdést a konzervatívabb tudósok, akik a digitális bölcsészetben nem látnak mást, mint csupán időleges fellángolást, furcsa hóbortot. Szerintük a digitális bölcsészet nem különbözik a posztmodern vagy a multikulturális, esetleg a posztgyarmati témák és hasonlók felbukkanásától, és olyanok lesznek, mint más „tudományos divatok”, amelyek aztán rendre rövid életűeknek bizonyultak. ${ }^{9}$ Ezek a megnyilatkozások igen lenézők, és valójában nem vitatják, de el sem ismerik a digitális bölcsészet alapvetéseit és annak összetett természetét.

\section{Együtt}

Olyan véleményekkel is találkozni azonban, amelyek a digitális bölcsészetet éppen az összefüggésekben találják meg. Bármelyiket nézzük is a fentiek közül, a digitális bölcsészet egy tudományterület és egy módszertan házasságából születik meg, amelyben talán minden eddiginél fontosabb szerepet kap a különböző kutatók közötti

6 Berry and Fagerjord, Digital Humanities, 148-149.

7 Carl Straumsheim, „Digital Humanities as a »Corporatist Restructuring «, Inside Higher Ed, 2016. máj. 6., https://www.insidehighered.com/news/2016/05/06/article-criticizes-impa ct-digital-humanities-colleges.

8 Daniel Allington, Sarah Bouillette, David Golumbia, „Neoliberal Tools (and Archives): A Political History of Digital Humanities," Los Angeles Review of Books, 2016. máj. 1., https ://lareviewofb ooks.org/article/neoliberal-tools-archives-political-history-digital-human ities/; Alan Jacobs, „Crititiquing the Critique of Digital Humanities,” The New Atlantis, 2016. máj. 2., http://text-patterns.thenewatlantis.com/2016/05/critiquing-critique-of-digital.html.

9 Stanley Fish, „The Old Order Changeth,” New York Times, 2011. dec. 26., https : //opinionator.b logs.nytimes.com/2011/12/26/the-old-order-changeth/. 
együttműködés. Ilyen módon - a bölcsészeti entitások közül - kiemelkedően függ a tudományos hálózattól is. Ezek a komponensek együttesen új eredményeket produkálnak, amelyeknek lényeges attribútuma, hogy új formában jelennek meg. Az egész „építmény” fontos jellemzője, hogy technikailag és strukturálisan egy új infrastruktúra köti össze részeit és szereplőit. ${ }^{10}$

\section{A digitális bölcsészet kritériumai}

Ezek a diskurzusok a lényegi problémákra fókuszálnak a digitális bölcsészet területén, olyanokra, amelyekkel fontos nyíltan szembenézni, és érdemes világosan elősorolni az érveket és ellenérveket is. E viták kulcsfontosságúak lehetnek a bölcsészettel foglalkozó szakmák megújulásához és a fejlődés fenntarthatóságához, még akkor is, ha láthatóan a kritikai megszólalások gyakran összekeverik a lehetséges megközelítéseket, és ezáltal bonyolultabbnak és nehézkesebbnek tűnik a jó válaszok megtalálása. Ezek a viták nem fognak egyhamar megszűnni: számítani lehet arra a forgatókönyvre is, hogy hosszú távon velünk maradnak. Fontos hatásuk, hogy újfajta gondolkodást ösztönöznek, továbbá a fejlődő metodológiákkal kapcsolatos állásfoglalást és a felhasznált eszközök folyamatos javítását és tökéletesítését is eredményezik. Ez a folyamat nyilván az érintett szakterületek mindegyikére pozitív hatást gyakorolhat, érdekesebb és eredményesebb új utakra is vezethet.

Ahhoz, hogy ezeknek a vitáknak hozadéka legyen, bizonyos feltételeknek teljesülnie kell. Elsősorban meg kellene határozni, hogy mi az a határ vagy mérföldkő, amelynek átlepése után a tudós egyértelműen a „digitális bölcsészet” területére kerül. Másodsorban fontos lenne megvitatni, hogy a digitális bölcsészetet „csak” egy új módszernek vagy „már” egy új tudományágnak tekintjük. Ez utóbbi - mint láttuk „politikai döntés” egyben, amelynek szakmapolitikai és támogatási következményeivel is számolni kell. Harmadik feltételként ki kellene fejleszteni egy olyan infrastruktúrát, amelynek segítségével a digitális bölcsészet művelésének területei és az alkalmazott technikák használata nem hárulna egyedül a kutatókra, hanem platformszerü általános segítséget és integrált eszközöket kapnának. Ezáltal a terület és a módszer hasznosíthatósága többek számára elérhetővé válik, és a projektek hosszú távon is továbbfejleszthetők maradnak. Végül fontos lenne kicsit a jövőbe pillantva átgondolni, hogy az előbbi válaszoknak mik lesznek, lehetnek a következményei a bölcsészeti tudományokban.

Kritériumként a következőket vethetjük fel, akár vitaindítónak is:

- A létező forrásanyag feldolgozható legyen digitálisan, hogy új szemszögből lehessen az anyaghoz hozzáférni, elemezni és vizualizálni. A bölcsészeti eredeti forrás - jelentős részben - írott szövegekből fog állni. Ezt a digitális bölcsész fel fogja dolgozni olyan formában, hogy ezt az anyagot és a végrehajtott műveletek eredményeit a folyamat végén grafikailag is meg lehessen „mutatni”, nem

10 Matthew Kirschenbaum, „What Is Digital Humanities and What's It Doing in English Departments?” in Debates in the Digital Humanities, eds. Matthew K. Gold and Lauren F. Klein, 3-11 (Minneapolis, Minn.: University of Minnesota Press, 2012), 4, https ://doi .org/10.5749/minnesota/9780816 677948.001 .0001$. 
csak szövegként. A grafikai megjelenítés alatt gondolhatunk földrajzi térképre, gráfokra, vektorokra, grafikonokra stb.

- A forrásanyag olyan mennyiségi paraméterekkel rendelkezik, hogy a kutatónak számítástechnikai eszközöket kell alkalmaznia ahhoz, hogy a korrekt és időben belátható feldolgozásra egyáltalán remény legyen. Ezért új eszközöket és új metodológiát kell alkalmaznia. Ellenérvként felhozható, hogyha csekély méretű forrásanyagot használ a kutató, akkor a hagyományos eszközök és módszerek is megfelelnek az anyag feldolgozásához, viszont amennyiben a forrásanyag mérete átlép egy bizonyos küszöböt, a hagyományos eszközök már nem lesznek elegendőek. Példának okáért az Árpád-kori fennmaradt forrásanyagot hagyományosan még fel lehet dolgozni, de már az Anjou-kori anyag túllépi ezt a határt, és itt már új eszközökre van szükség a teljes értékü és korszerü feldolgozáshoz. Megjegyzendő, hogy Magyarországtól nyugatabbra ez a határ korábban jelenik meg, többek közt az írásbeliség fejlettebb volta és a nagyobb méretű „forrásmegmaradás” okán. Mindez nem független attól, hogy a középkortudomány komoly forrás- és információs „hézagokkal” küzd régóta Európa-szerte.

- A forrásanyag megfelelően strukturált és szegmentált legyen ahhoz, hogy lehetségessé váljék a gépesített elemzése. Vagyis az anyagot elő kell készíteni ahhoz, hogy felosztása, szervezése s főképpen metaadattal való ellátottsága lehetővé tegye az algoritmikus feldolgozást. Nyilván az eredeti forrásokra nagyon komoly előmunkálatok várnak, mielőtt azokon algoritmusokat lehet futtatni. Ez a nehézség nem alábecsülendő, és ezen a ponton szorul a digitális bölcsész komoly informatikai tudásra és segítségre. Persze ideális esetben magának az anyagnak az előkészítését is lehet számítógépes eszközökkel elősegíteni. Mondhatnánk azt is, hogy ez a lépés az, amely megkülönbözteti a big data típusú előfeldolgozott anyagot a nyers adathalomtól.

- A forrásanyag feldolgozásához szükséges folyamatokat automatizálni lehessen, és új minőségben, új szemszögből tudja a kutató vizsgálni a szövegeket. Miután a forrásanyagot algoritmikusan fel lehet dolgozni, maguk az algoritmusok is tudományos fontosságot nyernek. Azoknak a fejlesztése, minősége és használata is tudományos eredménnyé, továbbá szakmai viták témájává válik. Újabb szempontként felmerül, hogy a vizsgált anyagot más algoritmusokkal később ismét fel lehessen dolgozni, akár más kutatók közreműködésével is. (Természetesen ez a folyamat az open data problematikáját is felveti.)

Azt mondhatjuk, ha ezen kritériumok közül legalább kettő teljesül, akkor talán lehet arról beszélni, hogy az adott projekthez hozzárendelhető a digitális bölcsészet címke.

\section{Együtt és külön}

A feltett kérdésekhez fontos még figyelembe venni azt is, hogy a digitális bölcsészet metódusa több hagyományos tudományágban alkalmazható. Ennek a ténynek a figyelmen kívül hagyása azzal a veszéllyel fenyeget, hogy egy interdiszciplináris irányt indítunk el, amely akarva akaratlanul oda vezethetne, hogy a jövőbeni erőforrások 
szétforgácsolódnak. Márpedig amit a történész, a nyelvész, az irodalmár stb. el akar érni a fent említett kritériumok alkalmazásával, az igen eltérő is lehet. A metodológiákban lehetnek (és valószínűleg lesznek is) hasonlóságok (amint a hagyományos metodológiákban is megfigyelhetők ezek), de a célok, a korlátok, a folyamat és a problematika más és más lesz. Sőt, a háttértudás, amely nélkül nem lehet tudományos haladás, ugyanannyira eltérő a digitális anyagok kezelésében, mint az analóg világban. Ezért azt érdemes átgondolni, hogy nem járna-e jobban mindenki, ha nem külön tudományágként közelítenénk meg a lehetséges újításokat, amelyeket a digitális bölcsészet nyújt. Esetleg jobb volna az erőfeszítéseinket két kihívásra fókuszálni : arra, hogy a hagyományosan dolgozó szakmák jobban elfogadják a módszertani újításokat, amelyeket a digitális világ nyújt, illetve hogy teremtsük meg a feltételeit és a lehetőségét annak, hogy a közösen alkalmazható eszközöket, kapacitásokat, algoritmusokat és stratégiákat meg tudják osztani egymás közt a tudósok.

\section{Együttmüködés}

$\mathrm{Az}$ is fontos tapasztalat e területen, hogy a legtöbb digitális bölcsész ab ovo abból indul ki, saját magának kell megszereznie az alkalmazandó eszközök használatáról való tudást, nemritkán az algoritmusok megtervezését (néha megírását) is, emellett nem elhanyagolható az adott forrásanyag ismerete és feldolgozási terve sem. Ezek a kritériumok összességében csak igen kevés és nagyon komplex tudású szakembert feltételeznek. Sajnos emiatt az ilyen jellegü tervek vágyak maradnak. Félresikerült torzókká válhatnak olyan projektek is, amelyek azonban kellő feltételek mellett sikeresek lehetnének. Minthogy a technikai fejlódés megállíthatatlan, és a digitális bölcsészet ezzel a haladással igen szoros függő viszonyban van, nem lehet elvárni, hogy a bölcsész ne csak a saját szakmájával és annak forrásaival tartson lépést, hanem annak teljes informatikai vertikumával is. Talán ennek az igen erős kihívásnak mégis vannak megoldásai. Kezdjük azzal, hogy az egyetemen a bölcsész nem magányosan létezik, például az adott egyetemen belül vannak más tanszékek, karok és intézetek, amelyek már rendelkeznek ismeretekkel ezen a területen. Lehet, hogy olyan nyersanyagra várnak vagy kooperáló partnerre, aki tartalommal tudja kiszolgálni elméleti konstrukciójukat. Ilyen partner lehet a könyvtár és/vagy az informatikai tanszék vagy intézet. ${ }^{11}$ Nagyon nagy szükség volna a különféle kooperációkra, talán együttműködési szerződéseket kellene kidolgozni, amelyek a felek számára megfelelő előnnyel bírnak. Egy ilyen „védernyő” alatt a közös projektek hosszú távú fenntarthatóságának esélyei is növekednének.

\section{A jövő víziója}

A jövőbe tekintve látszik, hogy ezen a területen a tudós még kevésbé lehet magányos, mint másutt. A digitális bölcsészethez szükséges megközelítések többet nyernének, mint veszítenének, ha a szükséges részszakterületek kutatói néha bepillanthatnának egymás munkájába. Például az e-science-es és a digitális bölcsész sokat tanulhatna egymástól. A megfelelő algoritmusok megtervezése és a programok megírása, a big

11 Berry and Fagerjord, Digital Humanities, 80-81. 
data szemlélet és a szövegkataszterek feldolgozása közös kihívásokat rejt, és hasonló megoldások után kiált.

Az újonnan létrejövő digitális bölcsészetnek (tartsuk azt akárminek is) az elnevezései, mint „e-”, illetve „digitális”, nem túl szerencsések. Elvégre a technika haladása mindig új kapukat nyit előttünk, és lehetetlen azt gondolni, hogy a tudományos munkát lehetséges lenne az aktuális legfejlettebb technika bevonása nélkül folytatni. Magától értetődő, hogy itt, a tudomány vizsgálódási területein kerülnek először bevonásra ezek az új technikák és technológiák. A valódi és fontos kérdés az, hogy a fejlődő technikát hogyan lehet az egyes tudományokban legjobban és legeredményesebben felhasználni. A lehetőségek, az előnyök és az új módszerek állandó keresését és kidolgozását természetes fejleménynek kellene tekinteni. Ugyanakkor el kell fogadnunk azt is, hogy az újjal szemben erős a szkepticizmus, a kritikai él, és az ellenállás magasabb szintje természetesnek mondható, mivel a bölcsészeti tudományok éppen a technológiákkal szemben előítéletesek és egyébként is meglehetősen konzervatív szemléletűek. Ez önmagában nem újdonság, nem is a mi korunk szülötte, hiszen távoli és közeli tudós újítások mind-mind ezzel a kérdéssel küszködtek Galileitől Einsteinig.

$\mathrm{Az}$ analóg és digitális módszertanú tudományok elválasztása sokszor inkább a tudományos iskolák és műhelyek szakpolitikai súrlódásaira vezethető vissza, hiszen a kutatói előmenetel, a projektfinanszírozás elnyerése, a pályázatok, a presztízs és hírnév a módszertanok megkülönböztetéséhez vezet, és mindez súlyos érdekellentéteket generál. Ezért is fontos tudomásul venni, hogy a digitális bölcsészet egyfajta függő állapotban van, ha úgy tetszik, állandóan kiszolgáltatott az informatikai feltételeknek és szaktudásnak. Vagyis arra kell számítani, azzal kell együtt élnünk, hogy a digitális bölcsészet az állandó megújulás és változás mellett állandó partnerkeresésben leledzik majd, mert a legújabb technikákat és a legjobb tudást - ami megvalósítja elképzeléseit, amivel lépést tud tartani - csak így kaphatja meg. Csak reménykedni lehet abban, hogy a lehetséges partnerek a másik oldalról hasonlóan gondolják mindezt, s nekik is szükségük van arra a tudásra és főként anyagra, amelyet a digitális bölcsész tud előállítani.

Az is látszódik ma már, hogy egyre hatékonyabbak az új eszközök és metodológiák, amelyeknek köszönhetően új eredmények jönnek létre. Olyanok, amelyek új kérdéseket tesznek föl, s néha régieket válaszolnak meg. Ez ma már igazolja e törekvések létjogosultságát. S az is meglehet, hogy előbb-utóbb nem kap majd különösebb megkülönböztetést az a projekt, amelynek eredményei részben vagy egészben a ma digitális bölcsészetnek nevezett szemlélettel és módszerrel keletkeztek. Innen nézve a tudományos eredmények lesznek a megkülönböztető és fontos tényezők, nem a felhasznált technika és metódus. Akkorára sikeresnek fogják elkönyvelni a digitális bölcsészet erőfeszítéseit, azok helyükre kerülnek, és a manapság zajló és élénk viták csupán felejthető háttérzajnak bizonyulnak. 


\section{Discussions and visions of the digital humanities}

This article reviews the latest controversies surrounding digital humanities in the United States and summarizes their main arguments. It discusses a set of questions that these controversies raise, starting with the lack of definition as to what criteria need to be met to qualify a project as a digital humanities project. It discusses whether the digital humanities is a methodology or a new branch of scholarship. It argues for the need to develop an infrastructure to support the pursuit of digital humanities projects. It concludes by identifying future implications of digital humanities research for scholarship in the humanities.

Keywords:

digital humanities, digital tools, digital methods 
